\title{
The 2016 Lasker Koshland Special Achievement Award recognizes Bruce Alberts' lifelong dedication to research, policy, and education
}

$\mathbf{T}_{\mathrm{h}}$ his year, the Lasker Foundation honors the outstanding contributions that Bruce Alberts (Figure 1) has made to our understanding of DNA replication, his leadership in scientific policy, and his commitment to advancing science education. Early in his career he was a preeminent researcher in the biochemistry of DNA replication, and he became one of the leading voices in the then-burgeoning field of molecular biology. For younger generations, his name is synonymous with the Molecular Biology of the Cell, an essential textbook for college-level biology students that he coauthored. Later, he became a key advisor for the project mapping the human genome, served two terms as president of the National Academy of Sciences (1993-2005), and was editor in chief of Science (2008-2013).

\section{Early life and training}

Alberts grew up in the northern suburbs of Chicago. He credits hands-on classroom experiences with inspiring his childhood curiosity. "I still remember having to give a presentation on how a television worked, which in those days was still a pretty new invention. It was the first of a long series of proofs for me that you learn best by teaching," Alberts told the JCI. Not knowing that "scientist" was even a career option, he was admitted Harvard University as a premed student. Alberts disliked the many "cookbook" laboratories required for his science courses but soon discovered the thrill of scientific inquiry under the tutelage of Jacques Fresco, a postdoctoral researcher in chemist Paul Doty's lab. His undergraduate research on nucleic acid structures was remarkably productive and resulted in publications in Nature and Proceedings of the National Academy of Science (1, 2).

Alberts abandoned the notion of medical school and continued his graduate studies in Doty's lab. His rapid pace of dis- covery, however, came to a grinding halt as a series of experiments failed. He had ambitiously set out to determine the sites from which DNA replication originated. He hit a wall, however, pursuing a hypothesis that in retrospect was completely incorrect. He had developed a theoretical model of DNA replication in which he posited that DNA replication began at the ends of chromosomes and created a tran-
The experience of failure provided an instructive lesson on the critical importance of experimental design, and it broadened his approach, such that he avoided single-minded research directions. For his postdoctoral research, he decided that he would try to carry out experiments that would provide informative results without relying on a rigid model, what we might now call an

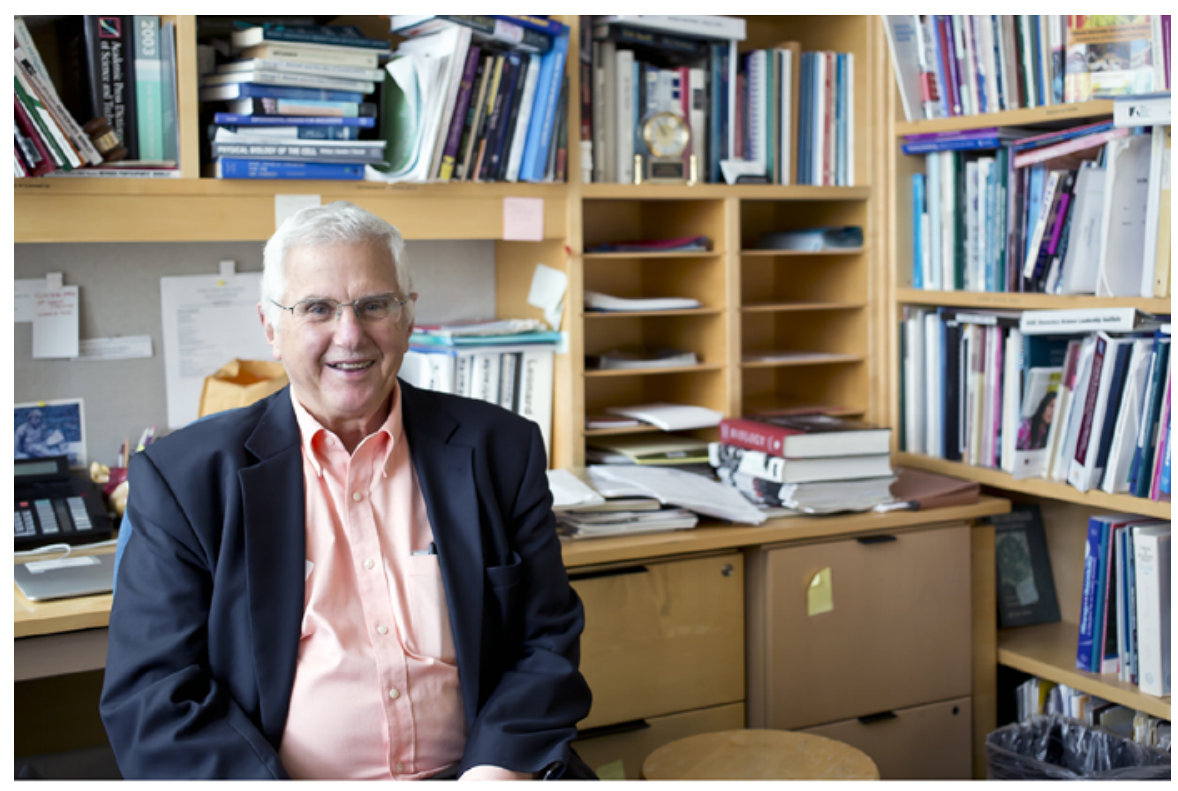

Figure 1. Bruce Alberts is the winner of the 2016 Lasker Koshland Special Achievement Award in Medical Science. The Lasker Foundation honors Bruce Alberts with this award for his exceptional lifetime achievements, including fundamental discoveries in the biochemistry of DNA replication, decades of leadership in national and international scientific organizations, and a lifelong dedication to improving science education. Image credit: Christopher Reiger.

sient DNA crosslink there. His lack of success led to him failing his first attempt at defending his thesis, which he later called "a blessing in disguise" (3). His thesis committee sent him back to the lab to finish the characterization of the DNA crosslinks that he had observed, even if they had nothing to do with DNA replication (4). unbiased approach. He decided that the best strategy for identifying the proteins needed for DNA replication might be to characterize those proteins in cellular extracts that bound to DNA. To this end, he created a DNA-cellulose column through which extracts were passed; the bound proteins were eluted with a salt solution and thereby purified. With this new tool in hand, Alberts started his own $\mathrm{lab}$ at Princeton. 


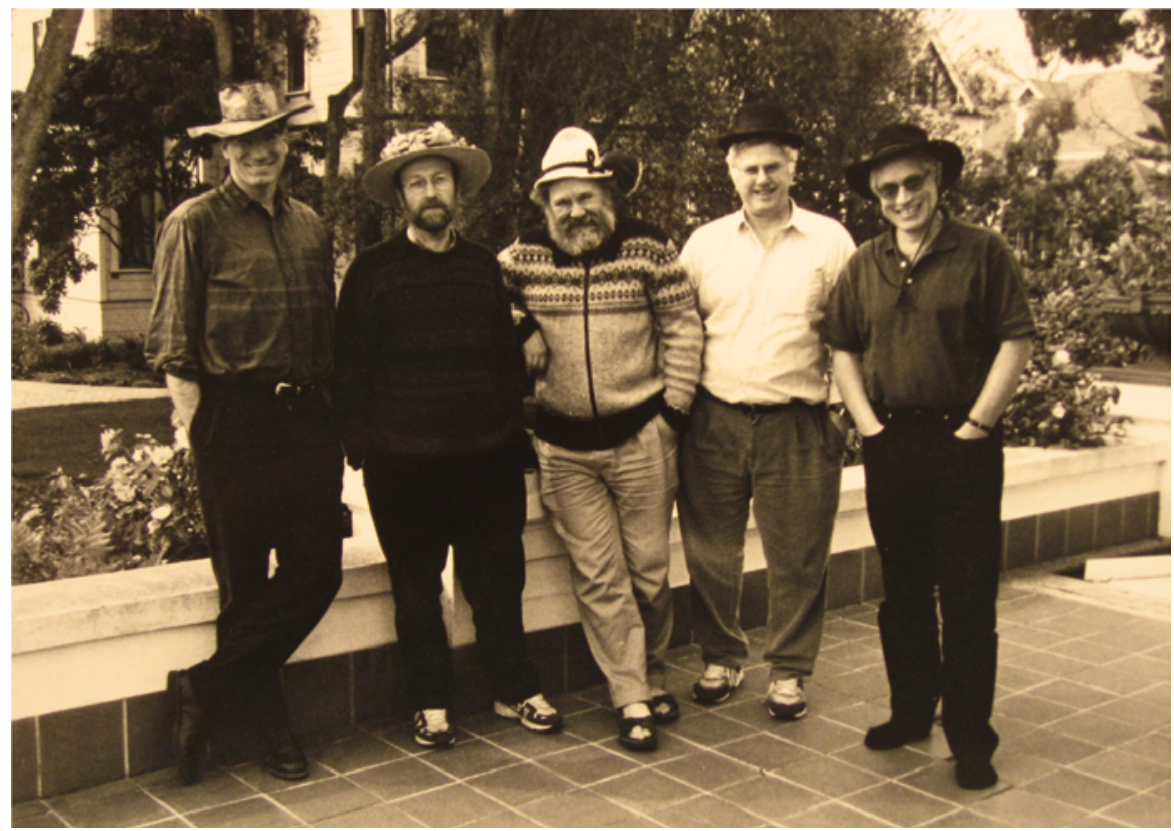

Figure 2. The authors of the fourth edition of Molecular Biology of the Cell in 2000. From left to right: Alexander (Sandy) Johnson, Julian Lewis, Peter Walter, Bruce Alberts, and Keith Roberts. Not pictured is coauthor Martin Raff.

\section{Identification of the essential components of DNA replication}

At Princeton, Alberts extensively studied the bacteriophage $\mathrm{T} 4$ as a model system for DNA replication. He was introduced to $\mathrm{T} 4$ as a postdoc in Geneva by Richard Epstein, who, along with Robert Edgar at Caltech, had been genetically analyzing T4 DNA replication. The tools of recombinant DNA had not yet been developed at this time, and for Alberts, the T4 system provided a ready source of replication proteins that could be biochemically isolated. His goal was to purify the necessary protein components to reconstitute replication in vitro. Using his DNA-cellulose column, he characterized the first single-stranded DNA-binding protein and showed that this protein, in addition to DNA polymerase, was necessary for DNA replication (5). We now appreciate that single-stranded DNA-binding proteins are absolutely conserved across kingdoms and are essential for DNA replication and repair.

Continuing this line of work, in 1975 his team reported five distinct $\mathrm{T} 4$ proteins that, when combined with single-stranded DNA-binding protein and DNA polymerase, could faithfully drive replication of double-stranded DNA in vitro (6). This study identified the essential protein components of DNA replication and established that the replication machinery required a complex of proteins. For this work, Alberts won the National Academy of Sciences Award in Molecular Biology.

In 1976, he was recruited to UCSF, where he continues to hold an appointment. In the ensuing years, his research team published an impressive series of papers biochemically detailing how $\mathrm{T} 4$ replication proteins interact with DNA to produce an active replication fork. These proteins were shown by Alberts' group and others to possess DNA helicase activity, synthesize RNA primers, and form the sliding clamp that provides high processivity to DNA replication (reviewed in ref. 7). His fundamental studies also described the fidelity of DNA replication and characterized $\mathrm{T} 4$ helicases, topoisomerases, and proteins required for DNA recombination (8-10).

One issue that dogged the field was a reconciliation of the differences in replication between the leading and lagging strand of DNA synthesis. Given the unidirectionality of DNA polymerase, DNA polymerase was thought to bind and dissociate from the lagging strand, which should reduce the rate of synthesis on that side of the fork. Yet, such differences were not observed; moreover, the rate of lagging strand synthesis was not sensitive to the concentration of DNA polymerase. Alberts therefore proposed a model in which the lagging strand is folded back upon itself, and as replication proceeds, the lagging strand is released and its DNA synthesis is restarted periodically by the same lagging strand DNA polymerase molecule. In this view, two DNA polymerases, one bound to each strand, remained fixed at the replication fork, harmoniously unifying synthesis on the leading and lagging strands (7).

\section{Writing the book on molecular biology}

In 1978, James Watson called Bruce Alberts to ask for help with a new textbook concept. Watson's vision was to marry the fields of biochemistry and microscopybased cellular biology. Watson persuaded Alberts and coauthors Dennis Bray, Julian Lewis, Martin Raff, and Keith Roberts that it would take them about two months spread over two summers to complete the task. This turned out to be a gross underestimate of the time needed, given the enormity of the project. Alberts himself noted that he had never even heard of endoplasmic reticulum when he was assigned to write that chapter and that cell biology seemed like a different world to him (11). After working 16-hour days for months in the summer of 1979 without satisfacto- 
ry progress, the team nearly abandoned the project. In 1983, after spending more than 365 days working together over the course of 5 years, the first edition of Molecular Biology of the Cell emerged. Now in its sixth edition, the book remains a fixture of undergraduate biology education, and it has shaped generations of biologists (Figure 2). Alberts said that the process profoundly shaped his subsequent research and continued to amaze him as the years went by. "Every time we write this textbook, you realize that we're further away from really understanding biology than we were the last edition. Not that we haven't learned a lot, but because we've learned enough so we know that the system is much more complicated than we ever imagined" (12).

\section{Science education hits home}

As Alberts and his colleagues were finishing Molecular Biology of the Cell, his own three children were enrolled in San Francisco city schools. His wife, Betty, herself a former school teacher, was president of the San Francisco PTA and enlisted Bruce's help in thinking about the science program in the public schools. The teachers expressed frustration at the lack of basic supplies for classroom lab experiences, and it struck Alberts that their classrooms were inadequate in the midst of a city with truly outstanding resources. From that realization, Alberts asked David Ramsay, then the Vice Chancellor for Academic Affairs at UCSF, for help securing resources for local schools and facilitating the transfer of surplus goods. This led to the formation of the Science and Health Education Partnership in 1987. "We convened some of the best science teachers in the district and had them tell us what UCSF could do for them," Alberts said. They went on to start an innovative program pairing UCSF graduate students and postdocs with area science teachers. This provided the teachers with better access to ongoing research and gave UCSF students a new view on the importance of science in the classroom. The program remains in place today, and Alberts recently shared with the JCI that an enormous source of pride for him has been the influence of this program on a number of outstanding research students, who ultimately shift- ed their focus to dedicate themselves professionally to full-time science education efforts.

Seeing that he could make a difference for his local schools, Alberts applied for a multimillion dollar National Science Foundation grant that led to the development of a program called City Science in San Francisco's public elementary schools. Working with superintendent Ray Cortines, Alberts told the JCI, "We had 100 teachers for a month of workshops the first summer, and Cortines gave all of San Francisco's elementary teachers six days off for science professional development for the next two years. It was fantastic. This program created a big inquiry-based science effort in the elementary schools of San Francisco." His efforts gave him a taste for what was possible when outstanding teachers and researchers worked together to improve education.

\section{Charting a course for the human genome project}

Around this same time, Bruce Alberts was asked to chair the Committee on Mapping and Sequencing the Human Genome formed by the National Academy of Sciences. Its members were an illustrious cast of scientists and Nobel Prize winners, including Sydney Brenner, Daniel Nathans, Stuart Orkin, Francis Ruddle, Shirley Tilghman, and Jim Watson among others. "I couldn't figure out for the world why they wanted me to chair this thing." Alberts told them, "I have never even thought about this. Why do you want me to chair this group of very contentious people all with strong opinions?" (13). It was precisely this unbiased leadership that the committee needed. Some members expressed reservations about turning biology into a large-scale enterprise, fearing this was a perversion of the science they knew. Alberts had previously espoused the opinion that small science is good science in a 1985 editorial (14), so perhaps a call for a concerted genome sequencing project would be better received coming from his committee.

Alberts decided that, before the committee could even discuss recommendations, they had to have a fundamental, realistic understanding of what the capabilities and constraints of sequencing technology and genomic mapping were at the time. They called in active researchers to inform them at each of their frequent meetings, and then added to the committee an impressive young researcher, Maynard Olson, who was on the forefront of genome sequencing research. Alberts credits Olson with helping the committee identify which overall strategies were even feasible. In the end, the committee united around the notion that the sharing of data from human genome project was so transformative that the project must proceed.

There were details to be worked out. Should the entire genome be sequenced or just the cDNA? At what point would the cost of sequencing be low enough to attempt the project? The committee had the prescience to appreciate that so-called "junk DNA" was likely to be important as well and determined that the genome must be sequenced in its entirety. They decided to first concentrate on sequencing simpler organisms, like budding yeast and the worm Caenorhabditis elegans, whose relatively smaller genomes could be sequenced at much lower cost. From such efforts, they predicted that sequencing techniques would become gradually less expensive; moreover, studies in these model organisms themselves proved highly informative. In 1988, the final recommendations were published (15) and were soon implemented by NIH Director James Wyngaarden, culminating in the 2001 copublication of the human genome by the International Human Genome Sequencing Consortium and Celera $(16,17)$. The process for completing the project remarkably followed the guidelines that had been recommended by the National Academy of Sciences Committee.

\section{A call for science education reform}

After his success with developing the blueprint for the human genome project, Alberts was tapped to be the full-time president of the prestigious National Academy of Sciences, a society of preeminent scientists tasked with advising the government on science and technology issues. Initially, he refused to be considered for the position, maintaining that he did not want to leave his lab at UCSF. Nine months later, he was informed that a committee at the National Academy had nevertheless selected him, requesting the courtesy of 


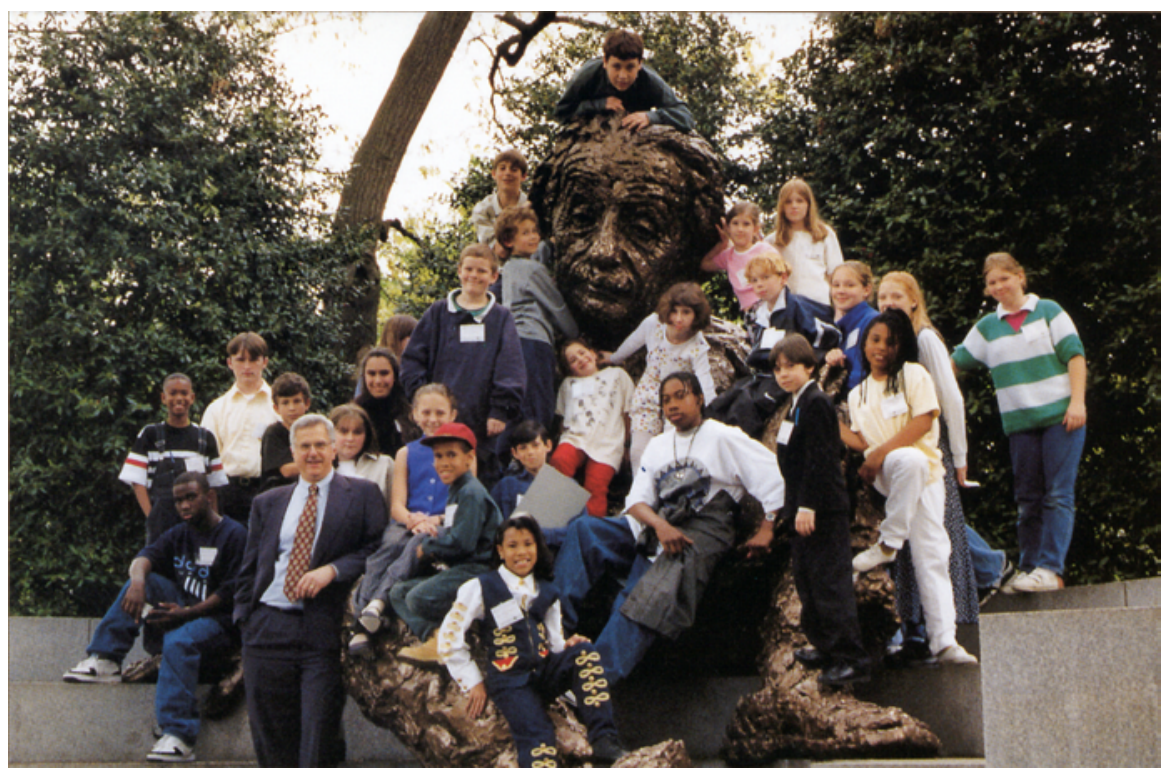

meeting in person to discuss the position. Caltech chemist Harry Gray and several other members of the committee flew out to Connecticut, where Alberts was working on an updated edition of Molecular Biology of the Cell. They were eventually successful in persuading Alberts that he would have a unique opportunity to make an impact on science education with the resources of the academy. Given all of his efforts on science education in San Francisco, the offer proved too enticing to refuse: the National Academy of Sciences would provide him with a platform to advocate for reforming and radically shifting how science is taught on a national scale.

During his first year as president, Alberts was immediately immersed in developing the National Science Education Standards (Figure 3). He brought teachers, education researchers, and scientists together to develop a consensus understanding of the opportunities and barriers that each group saw. "I went to the Academy because I saw it as a unique chance to bring the best scientists and the best of science to bear on science education for everyone at all levels," Alberts said (18). He was more than a figurehead on the project, and he himself would spend two years working on writing the standards as Chairman of the National Research Council. Numerous individuals, working through the National Com- mittee on Science Education Standards and Assessment, the Board on Science Education, the Division of Behavioral and Social Sciences and Education, and the National Research Council, worked tirelessly to develop the guidelines. After four years and evaluation by more than 18,000 referees, the National Science Education Standards were released in 1996 (19). This landmark document stressed the notion of teaching science through inquiry-based learning and understanding the scientific process, and it deemphasized the rote memorization of facts. Students should understand how to frame a question and gather evidence to inform a conclusion and appreciate that claims need to be reproducible in order to be substantiated. This type of logical problem solving would not only benefit future scientists but would improve science literacy for all students. The standards set out lofty principles and also had separate chapters addressing best practices in teaching, student assessment, design of school science programs, and support resources.

Aspects of these standards have been implemented in many schools across the nation, but Alberts would later become frustrated by the high-stakes testing culture that developed from the implementation of the No Child Left Behind legislation. "Against the advice of experts, the nation has even been mistreating teach- ers by grading them according to the annual test gains of their students, ignoring dominant out-of-school influences as well as research showing that teacher differences account for only about $10 \%$ of the variance in student test score gains in a single year," Alberts later wrote (20). He lamented the fact that education policy is dictated from the top down and that too often the needs of the teaching professionals are ignored. He remains a staunch advocate for drastically changing how science is taught and believes that universities must play a leading role in reshaping education. "College science courses are taught by scientists, and they define 'science education,' modeling for teachers and adults what should be done at lower levels. Most college faculty have not yet faced up to the urgent need to improve on the standard one-size-fits-all lecture format," Alberts wrote (21). The examples set in college-level classes are adapted to advanced placement classes and simplified to determine how high school and middle school science are taught. But with an emphasis on learning science facts and terms, the broader concepts and curiosity about discovery are lost. "If you look at a middle school biology text, it's probably the hardest book you're ever going to see," said Alberts (22).

Alberts shared with the JCI that, "The most important part of the standards 
was that it brought the science community together with the science educators and the people who were professional researchers on science education... When we ran that project, we made sure that the voices of all those people were heard. They got to know each other, and it has really created a long-lasting movement of people who deeply understand what is needed in science education."

In addition to his work on education policy, during his time as president, Alberts was also very active internationally with a number of partner organizations in other nations. He cochaired the InterAcademy Council, a coalition of science academies that advises on global issues, and worked on recommendations for building science infrastructure in developing nations, stressing the critical importance of such efforts. "I got a real education and new understanding of the importance that science institutions and scientists can play in every nation, no matter how poor they are," Alberts said.

\section{Remaining a strong voice in the science community}

After Alberts left the National Academy of Sciences, he subsequently became the editor in chief of Science magazine, where he served for 5 years. In addition to a commitment to publishing the very best research, Alberts used his time there to promote awareness of science education issues. During his tenure, Science published four special issues dedicated to ongoing challenges in science education, with experts contributing commentaries on technology in the classroom, active learning strategies, professional development for teachers, and education in the developing world. Science also sponsored contests for the best open-access science education websites and created a free website to disseminate articles about science education and annotated versions of research articles for high school students (23). These resources are intended to help students both here and abroad directly see science in action, beyond the typical textbook rendition.

While still at Science, Alberts was selected by President Obama as one of the first three US Science Envoys, tasked with increasing scientific cooperation with Muslim-majority nations. His efforts would be focused on Indonesia, in partnership with molecular geneticist Sangkot Marzuki, the president of the Indonesian Academy of Sciences. Together, they worked to establish the US-Indonesia Frontiers of Science Program, which hosts an annual meeting dedicated to bringing young Indonesian researchers together with their US counterparts. Though Alberts' time as Envoy has ended, the Frontiers of Science meetings continue, a lasting legacy of his outreach efforts, with the sixth meeting held in August 2016. Alberts is also currently serving on the scientific advisory board for the Indonesian Science Fund, the first merit-based competitive grant program in Indonesia.

$\mathrm{He}$ also remains very active in science education efforts, notably in his work as chair of the Board of Trustees of the Science Education Research Program, a nonprofit organization that was spun out from the National Academies in 2003. He is particularly passionate about exploring how we can enable school districts to function more effectively through empowering its best teachers to influence district policy, without requiring that they leave the classroom. He also is working on efforts turn the middle school cell biology curriculum on its head by presenting young students with the specific problems that a cell faces in trying to self-replicate and challenging them to think about how those might be solved. Through repeated observations of students using materials in real classrooms, Alberts and colleagues at the Science Education Research Program plan to test and refine such innovative approaches for teaching science.

When Alberts began his career in DNA replication research, he surely could not have anticipated the broader role that he would come to play in science education and diplomacy. But his time as president of the National Academy of Sciences opened his eyes to the importance of this work. "I came to realize that science is much more important for the world than most scientists suspect. The scientific values of honesty, respect for evidence, openness, and tolerance are critical for every nation. And scientific approaches to problem-solving are essential everywhere for meeting a huge range of societal challenges" (24). The Lasker Foundation celebrates his commitment to and impact on diverse realms of science, from research to education and global outreach, with this special achievement award.

\section{Sarah Jackson}

1. Fresco JR, Alberts BM, Doty P. Some molecular details of the secondary structure of ribonucleic acid. Nature. 1960;188:98-101.

2. Fresco JR, Alberts BM. The accommodation of noncomplementary bases in helical polyribonucleotides and deoxyribonucleic acids. Proc Natl Acad Sci U S A. 1960;46(3):311-321.

3. Alberts B. A wake-up call. Nature. 2004 431(7012):1041.

4. Alberts BM, Doty P. Characterization of a naturally occurring, cross-linked fraction of DNA. 1. Nature of the cross-linkage. J Mol Biol. 1968;32(2):379-403.

5. Alberts BM, Frey L. T4 bacteriophage gene 32: a structural protein in the replication and recombination of DNA. Nature. 1970;227(5265):1313-1318.

6. Morris CF, Sinha NK, Alberts BM. Reconstruction of bacteriophage T4 DNA replication apparatus from purified components: rolling circle replication following de novo chain initiation on a single-stranded circular DNA template. Proc Natl Acad Sci US A. 1975;72(12):4800-4804.

7. Alberts BM. Prokaryotic DNA replication mechanisms. Philos Trans R Soc Lond, B, Biol Sci. 1987;317(1187):395-420.

8. Hibner U, Alberts BM. Fidelity of DNA replication catalysed in vitro on a natural DNA template by the $\mathrm{T} 4$ bacteriophage multi-enzyme complex. Nature. 1980;285(5763):300-305.

9. Liu LF, Liu CC, Alberts BM. T4 DNA topoisomerase: a new ATP-dependent enzyme essential for initiation of $\mathrm{T} 4$ bacteriophage DNA replication. Nature. 1979;281(5731):456-461.

10. Bedinger P, Hochstrasser M, Jongeneel CV, Alberts BM. Properties of the T4 bacteriophage DNA replication apparatus: the T4 dda DNA helicase is required to pass a bound RNA polymerase molecule. Cell.1983;34(1):115-123.

11. Bruce Alberts on Working with Jim Watson on Molecular Biology of the Cell [video]. Cold Spring Harbor Laboratory Oral History Collection. http://library.cshl.edu/oralhistory/interview/ james-d-watson/writer/alberts-workingwith-jim-watson-on-molecular-biolo/. Recorded August 22, 2008. Accessed August 23, 2016.

12. Bruce Alberts on Genome Research and the New Biology [video]. Cold Spring Harbor Laboratory Oral History Collection. http://library.cshl.edu/ oralhistory/interview/genome-research/changesover-time/alberts-genome-research-and-thenew-biology/. Recorded August 22, 2008. Accessed August 23, 2016.

13. Bruce Alberts on NAS: Committee on Mapping and Sequencing the Human Genome [video]. Cold Spring Harbor Laboratory Oral History Collection. http://library.cshl.edu/oralhistory/ interview/genome-research/challenges-hgp/ alberts-NAS-committee-on-mapping-andsequencing/. Recorded August 22, 2008. Accessed August 23, 2016. 
14. Alberts BM. Limits to growth: In biology, small science is good science. Cell. 1985;41(2):337-338.

15. National Research Council (US) Committee on Mapping and Sequencing the Human Genome. Mapping and Sequencing the Human Genome. Washington (DC): National Academies Press (US); 1988. http://www.ncbi.nlm.nih.gov/ books/NBK218252. Accessed August 23, 2016.

16. Lander ES, et al. Initial sequencing and analysis of the human genome. Nature. 2001;409(6822):860-921.

17. Venter JC, et al. The sequence of the human genome. Science. 2001;291(5507):1304-1351.

18. Bruce Alberts on Improving Science Education in the U.S. [video]. Cold Spring Harbor Laboratory Oral History Collection. http://library.cshl.edu/ oralhistory/interview/scientific-experience/ scientific-experience-mentoring/alberts-improving-science-education-in-the-united/. Recorded August 22, 2008. Accessed August 23, 2016.

19. National Committee on Science Education Standards and Assessment, National Research Council. National Science Education Standards. Washington (DC): National Academies Press (US); 1996. http://www.nap.edu/read/4962/ chapter/1. Accessed August 23, 2016.

20. Alberts B. Empowering great teachers. Science. 2016;351(6270):207.
21. Alberts B. Prioritizing science education. Science. 2013;340(6130):249.

22. Bruce Alberts on Science Education in the U.S. [video]. Cold Spring Harbor Laboratory Oral History Collection. http://library.cshl.edu/ oralhistory/interview/scientific-experience/ becoming-scientist/alberts-science-educationin-the-us/. Recorded August 22, 2008. Accessed August 23, 2016.

23. Science Education Portal. Science. http://portal. scienceintheclassroom.org/. Accessed August 23, 2016.

24. Alberts B. After 5 years at Science. Science. 2013;340(6136):1015. 